\title{
The Controversy of "Nur Muhammad" Concept in Malay Manuscripts: Tajalliy and Faidhun's Perspective Study
}

\author{
Sangidu $^{1}$, Harun Joko Prayitno ${ }^{2}$, Elita Ulfina ${ }^{3}$, Sherif Sa'ad El-Jayyar $^{4}$, Awla Akbar Ilma ${ }^{5}$ \\ \{sangidu@ugm.ac.id, harun.prayitno@ums.ac.id,ulfiana.elita19@gmail.com, \\ dr.shariefaljayyar@yahoo.com, awlaakbar24@gmail.com \}
}

Universitas Gajah Mada, Yogyakarta, Indonesia ${ }^{1}$, Universitas Muhammadiyah Surakarta, Surakarta, Indonesia ${ }^{2}$, IAIN Surakarta,Surakarta, Indonesia ${ }^{3}$, Bany Suef University, Egypt ${ }^{4}$, Suez Canal University, Egypt $^{5}$

\begin{abstract}
The issue of the concept of "Nur Muhammad" in the general perspective still cannot resolve the nature of beings and life. This research is intended to explore the controversy surrounding the concept of "Nur Muhammad", focusing particularly on the manuscript Hikayat Nur Muhammad but also considering other Malay manuscripts to explore how "Nur Muhammad" was understood. In the context of Islamic philosophy, the concept of tajalliy (emanation) holds that everything in the universe, including human beings, originate from the "Nur Muhammad", the Almighty, viewed as the source of all light. Disagreement over the process through which the universe and its contents were created, including human beings, has created conflict between the Ahlu Wachdatil-Wujūd (Syaikh Hamzah Fansuri, Syaikh Syamsuddin As-Samatrani, and their followers) and the Ahlu Wachdatisy-Syuhūd (Syaikh Nuruddin Ar-Raniry and his followers). This research has found that the Ahlu Wachdatil-Wujūd have held that the process through which "Nur Muhammad" spread from ta ayyun tsāniy (second reality) or a'yān tsābitah (fixed reality) to a'yān khārijiyyah (reality outside Dzāt, Wujūd, and His essence) was not a process of creation, but rather one of radiance or tajalliy. Meanwhile, the Ahlu Wachdatil-Syuhūd held that "Nur Muhammad" was not a radiance or tajalliy of light, but the bestowing of full power or faidhun, such that the light remained strong even as the beings granted power became increasingly distant.
\end{abstract}

Keywords: hikayat nur muhammad, malay manuscript, kontroversi nur muhammad, tajalliy, faidhun, tafwīdh.

\section{Introduction}

Malay manuscripts are the creative products of the Malay people, written by authors in the Archipelago (such as Syaikh Hamzah Fansuri, Syaikh Syamsuddin As-Samatrani, Syaikh Abdurrauf As-Singkeli, Syaikh Abdush Shamad bin Abdullah al-Jawi al-Falimbani, Syaikh Yusuf Al-Makassary, Syaikh Nawawi al-Bantani Al-Jawi, and Syaikh Muhammad Arsyad alBanjari, as well as authors outside the Archipelago, such as Syaikh Nuruddin Ar-Raniry, Syaikh Muhammad bin Fadhlullah al-Burhanpuri al-Hindi, Syaikh Daud bin Abdullah al-Fattani, and Syaikh Zainal Abidin bin Muhammad al-Fattani [1]. They produced a number of manuscripts dealing with various religious topics, such as fiqh (Islamic jurisprudence), manthiq (logic), and tasawuf (mysticism) ([2], [3], [4]). 
Although the form of the manuscript has sometimes been damaged so it is difficult to read [5]. However, it contains very rich contents [6]. These manuscripts represent a veritable treasure passed over generations, encoding the knowledge of their authors so that said knowledge may be read, expanded, and used by subsequent geneducationerations of Malays. Malay authors such as those mentioned above have produced works that have been born and grown in Malay society, thereby becoming a part of said society ([7], [8]).

The Malays are a people who share a language and culture and live in the Malay realm, including Brunei Thailand (Pattani), Sailand (Sri Lanka), Burma, Malaysia, South Philippines, Singapore, Sumatra, coastal Sulawesi (Bugis, Makassar, Buton), coastal Kalimantan, coastal Java, and Bali (Sumbawa). The inclusion of these regions in the Malay realm is based on the production of manuscripts written in the Malay language using the Jawi (Arab-Malay) script ([9], [10]) [11].

To date, more than 10,000 Malay manuscripts have been identified. Spread throughout the Malay realm and Europe, many of these manuscripts have been ignored and neglected, as the proper treatment of such manuscripts requires much time, energy, money, and expertise - in other words, fluency in the language used in the manuscript [12].

One manuscript that is interesting for discussion is Hikayat Nur Muhammad, an anonymous manuscript held at the Aceh Special Administrative Region Provincial Museum, Banda Aceh. In tasawuf, "Nur Muhammad" (the essence of Muhammad or the spirit of Muhammad) is a being created by Allah SWT, followed only later by the universe and human beings. As such, the concept of "Nur Muhammad" is closely linked to humans' desire to attain high status and become Insan Kamil (perfect beings).

Every being was created by "Nur Muhammad", and "Nur Muhammad" was created by the light of Allah SWT. In other words, every being (everything in this universe, including humans) receives "Nur Muhammad", but the only beings viewed as perfect are the prophets, and the most perfect of these is the Prophet Muhammad SAW. Importantly, "Nur Muhammad" is not the Prophet Muhammad SAW and the Prophet Muhammad SAW is not "Nur Muhammad". However, "Nur Muhammad" takes the form of the Prophet Muhammad SAW. As such, even after the death of the Prophet, "Nur Muhammad" remains eternal and present in every living being, particularly those who have brought themselves closer to Allah SWT, such as the family and descendants of the Prophet Muhammad SWT, the believers, the pious, the devout, and those who attain the status of Insan Kamil [13]. As such, manuscripts containing the concept of "Nur Muhammad" are interesting for further study, to ensure that the contents of their text can be presented for reading, understanding, embodied, and ultimately used to promote human happiness both on earth and in the afterlife.

The Malay manuscript titled Hikayat Nur Muhammad (the Story of Nur Muhammad) is held at the Aceh Special Administrative Region Provincial Museum, Banda Aceh. Measuring 18 x $10.7 \mathrm{~cm}$, it has been given the code M.S. Inv. 4208, Written on smooth European paper with fine milling strips, it is beautifully written and includes as its watermark the Arms of Groningen, 1755 (consisting of a crowned shield, with wreathes on the left and right, and a table with legs forming a face-down $\mathrm{S}$ ). This manuscript has yet to be subject to any academic study. As such, three research problems are posed by this manuscript: the manuscript itself, its editing, and its contents - the last of these, in this case, being the concept of "Nur Muhammad". In this article, the contents of several Malay manuscripts dealing with the concept of "Nur Muhammad" will be examined and discussed.

As such, the practical goal of this research is to understand the substance of the manuscript's contents as related to the concept of "Nur Muhammad". This includes revealing 
and explaining these contents, such that they can be understood by readers. Meanwhile, the theoretical goal of this research is to offer readers an understanding of the concept "Nur Muhammad" to ensure that its contents can be applied in religious and national life, such that readers can realize a degree of "perfect being", leading to happiness both physical and mental, worldly and heavenly.

\section{Method}

In order to examine the manuscript "Hikayat Nur Muhammad" concerning the understanding and disclosing the contents of the text "Hikayat Nur Muhammad" in relation to the concept of "Nur Muhammad", it is necessary to use the approach of reception theory as the guidance and reception method for the implementation. Therefore, this article will discuss reception theory and its method in general.

Literary reception theory is a discipline that considers the role of the reader important in giving meanings of literary texts. The relationship between literature and readers contains aesthetic implications [14]. Accordingly, the literary text in this case the text "Nur Muhammad" can be regarded as an aesthetic object after being read or concretized by readers [15]. The position of the reader is very important [16]. This theory reveals that literary works are areas of indetermination or uncertainty that require readers to respond [17]. The reader is required to have the stock of knowledge and experience in this process [18].

The use of reception method should be adjusted to the conditions of the literary work that is being or will be studied. Accordingly, the literary work created some time in the past can be recognized through the manifestation of transformation or through the manifestation of the text's response form [19]. If the form of the transformed text or response text varies, it shows an intensive response to the text. The response of readers can also be traced to various other texts [19]. Therefore, the response of a text to other texts can be traced using three methods. First, experimental method, which is a method of presenting particular texts to particular readers, both individually and in groups, so that they give a response. Such research can be conducted using a list of structured questions [20]. Respondents' answers from the structured questionnaire are then analyzed systematically and quantitatively. In addition, the respondents can also be elicited using non-directed and free analysis. The answers to the question list are then analyzed qualitatively [19], [20]. Second, text criticism method, which is a method that traces the development of reader responses through reviews, criticisms, comments, analysis or research in the form of bachelor's thesis, master's thesis, or dissertation ([19], [20]). Third, intertextual method, which is a method that traces response through other texts that respond the text, for example by processing, distorting, resisting, or rewriting the text. This can be performed through copying, adaptation, or translation ([19], [20]). In examining the manuscript "Hikayat Nur Muhammad", those three methods of reception cannot be entirely utilized, but only text criticism method and intertextual method are utilized. 


\section{Result and Discussion}

\section{A. Understanding "Nur Muhammad"}

Humans are born in a state of fitrah (purity and cleanliness), in which they have committed no good deeds or bad ones. As they grow and learn, from birth to death, they are hoped to remain in a state of fitrah. As such, there are three major questions related to human life: when were humans first created? For what have humans been created? Where do humans go after their life on earth is finished? The process undergone by humans, from birth to death, is expected to occur under the protection, direction, guidance, and radiance/bestowment of "Nur Muhammad". To delineate the concept of "Nur Muhammad" and reveal it to readers, thereby easing its application in everyday life and promoting happiness in body and mind, on earth and in heaven, it is necessary to provide an understanding of "Nur Muhammad".

In Arabic, the word nūr means "light", something that shines on an object, ensuring that said object is clearly visible. According to the linguist Ibrahim Anis, in his al-Mu'jamul-Wasit, the word nūr refers to a "light that makes the eyes see". Meanwhile, Muhammad Mahmud Hijazi, an expert in tasawuf, understands nūr as a "light captured by the senses, and with which the eyes can see something. Metaphorically, this has developed into an understanding of "direction and rational thought".

According to Tabataba'i, the author of the al-Mĩzan interpretation, the earliest understanding of the word nūr was "something that appears on its own, and also makes sensual objects (implicit, instinctive) apparent". This meaning then developed into a broader understanding, in which every sense is viewed as nūr or as having nūr, and with which all that is sensual becomes apparent. This understanding then developed further, covering the non-sensual, such that the mind itself could be considered nūr as it reveals the abstract.

Ibnu Sina, when asked the meaning of nūr in Q.S. An-Nur [24]:35, answered that nūr contains two meanings: an essential meaning and a metaphorical meaning. The essential meaning is "perfection, clarity", as nūr itself is fundamentally "clear". Meanwhile, two metaphorical meanings can be identified: "something that is good", or "something that leads to goodness".

Al-Isfahani, an expert in tafsir (interpretation), divided understandings of nūr into material (worldly) and spiritual (heavenly) ones. As understood materially, nūr is the light that can be seen/perceived on earth. This can be divided into two further understandings. Abstractly, nūr is understood as the light that can only be perceived by the heart's eye (bashirah), while concretely or sensually (mahsūs) nūr is understood as the light perceived by the eyes in one's head. Meanwhile, spiritually, nūr can be understood as the light perceived in heaven.

In the Quran, the word nūr is mentioned 43 times, with no less than three meanings. First, the word nūr is used to mean "light itself", as in Q.S. Yunus [10]:5. Second, the word nūr is used to mean "hint or indication", as in Q.S. al-Hadid [57]:9. Third, the word nūr is used to mean "the Quran", as in Q.S. al-Taghabun [64]:8.

As such, the essential meaning of nūr is "hint or indication", as nūr-be it used to indicate light, a hint, or the Quran - serves to provide guidance to people seeking the path to truth. The Prophet Muhammad SAW is also known as nūr, as He is believed to have guided people towards the path of righteousness. This is mentioned in the al-Munawwir dictionary, which explains that nūr refers to the Prophet. 
Al-Ghazali, in his Misykatul-Anwār, wrote that the Quran's position relative to the mind's eye is akin to sunlight's position relative to the physical eyes. This light brings perfect sight. As such, the Quran is appropriately termed nūr, similar to how the rays of the sun are known as light.

Al-Ghazali explains that the word nūr or light has four understandings. First, light as something perceptible to the eyes, though nūr cannot see itself. Second, the light of sight, which makes everything perceptible to the eyes; this nūr is grander than the first type. Third, the light of aqli, that which concretely manifests the rational; all hidden by the darkness is made real and perceptible by nūr. Fourth, nūrul-Chaq (Allah SWT), who concretizes the imperceptible, all that is hidden from sight, such as angels.

According to al-Ghazali, the only true nūr is Allah SWT, while all light but that referring to Him is mere metaphor, without any true manifestation. As such, al-Ghazali distinguishes nūr as understood by laypersons and nūr as understood by religious scholars.

As understood by laypersons, nūr refers to something visible or perceptible. Light is something that becomes apparent on its own, or that makes something else visible. Meanwhile, nūr as understood by religious scholars, is a "soul that sees". Here, a soul that sees is equivalent to perceptible light in that it is necessary for visibility and understanding. In fact, a "soul that sees" may be considered more important, owing to its greater abilities for application.

Aside from the word nūr, defined above, it is also necessary to define "Muhammad", which refers to the Prophet Muhammad SAW. Sufis recognize the Prophet Muhammad SAW in their own way. Al-Tustury, for example, recognizes the Prophet Muhammad SAW as the foundation for the sacred earth and creation. The Prophet Muhammad SAW is Azali, as the Prophet is part of Allah SWT, or, more specifically, part of His nūr. Another opinion was voiced by Amin alQurdy, who stated that the Prophet Muhammad was Ainul-Wujūd, manifested as the source of everything.

From this discussion, it can be understood that "Nur Muhammad" is radiated/ bestowed from the Prophet Muhammad SAW, graceful and virtuous, in body and soul. Ibnu Khatib wrote that "Nur Muhammad" and His light make the moon shine perfectly, as the sun shines with "Nur Muhammad" (https://ahlulbaitrasulullah. blogspot.co.id/ 2014/01/nur-muhammad-prosespenciptaan-dzat.html, downloaded on 16 February 2018 at 08:10).

The concept of "Nur Muhammad", in a Sufistic context, may be understood as follows. The life (soul) of a human consists of four elements: Wujudul-Lāh, 'Ilmul- Lāh, Nurul- Lāh, and Syuhūdul-Lāh. The first, descended from the Dzāt of Allah, is "Nur Muhammad", which serves as the soul of all creation, including human beings (Ar-Raniry in Mā'ul-Chayāt, n.d.:5). As such, in a mystic context, "Nur Muhammad" was the first being created by Allah SWT; only afterwards did He create the universe and humanity. "Nur Muhammad" (محمد نُوْرُ) is often understood as Hakikat Muhammad (the essence of Muhammad; المحمدية الحقيقة) and Ruh Muhammad (the soul of Muhammad; محمد رُوْحُ). The concept of "Nur Muhammad" was first discussed and expanded by a Sufi known as Abu Abdullah Husain bin Mansur al-Hallaj, better known as al-Hallaj.

In Ensiklopedia Islam (The Encyclopedia of Islam), it is stated that "Nur Muhammad" or the "Light of Muhammad", in Sufi teachings is the understanding that Allah SWT first created "Nur Muhammad", and that all other beings were created from this light. "Nur Muhammad" is manifested not only in the Prophet Muhammad SAW, but also in all of the prophets. "Nur Muhammad" first emerged in Adam, and then in the other prophets, but only in the Prophet Muhammad SAW was it perfectly realized. As such, the Prophet Muhammad SAW is known in Sufism as al-Insanul-Kāmil (the Perfect Human). No human has been or will ever be more perfect and more glorious than the Prophet Muhammad SAW. The idea or concept of "Nur Muhammad" was first proposed by an Iraqi Sufi named Abu Muhammad Sahal bin 'Abdullah at-Tustari, best 
known as Sahal Abdullah al-Tustari. Further contributions to the "Nur Muhammad" concept were made by al-Hallaj, Muchyiddin Abu Abdullah Muhammad ibn Ali ibn Muhammad ibn Ahmad ibn Abdullah Hatimi at-Ta'i, best known as Ibnu Arabi; and Abdul Karim ibn Ibrahim ibn Abdul Karim ibn Khalifah ibn Ahmad ibn Mahmud al- Jilli, best known as Abdul Karim alJilli.

According to Sahal Abdullah al-Tusturi, during Creation Allah SWT made Adam of "Nur Muhammad". He also created the light of the prophets also came from "Nur Muhammad", as well as the light of the kingdom of heaven and the malākūt (angels). So too did the light of the world come from this light, the "Nur Muhammad".

Three centuries after Sahal Abdullah al-Tusturi, Ibnu Arabi wrote that "Nur Muhammad" is the seed of humankind. As such, "Nur Muhammad" existed in its essence before Adam, even though on Earth the Prophet Muhammad SAW was descended from Adam. As such, should all of the light of the Prophet SAW be placed in `arsy, the `arsy would be divided. Should all of this light be placed in seventy chijab (vessels), still it would spill out. Should all beings be gathered, with the light of glory upon them, "Nur Muhammad", they would take flight before falling.

The concept of "Nur Muhammad" is linked to human achievement (Sufism) and perfection (Insan Kamil), such that people who have achieved the highest level of humanity are those with "Nur Muhammad" (the essence of Muhammad or the spirit of Muhammad). As such, al-Jilli argued that the beings created of "Nur Muhammad" are the beings created by the light of Allah. As such, every being and thing contains "Nur Muhammad", but perfection belongs only to the prophets, with the most perfect being the Prophet Muhammad SAW. "Nur Muhammad" is not the Prophet Muhammad SAW, and the Prophet Muhammad SAW is not "Nur Muhammad". However, "Nur Muhammad" took the form (vessel) of the Prophet Muhammad SAW. As such, although the Prophet Muhammad SAW has died, "Nur Muhammad" remains eternal and present in those seeking life with Him, including Sufi scholars, the descendants of the Prophet Muhammad SAW., the pious who are solemn in their prayers, and those who go on the hajj (compare: https://ahlulbaitrasulullah.blogspot.co.id/2014/01/ nurmuhammadprosespenciptaandzat.html, downloaded on 16 February 2018 at 08:10).

\section{B. The Controversy of Sufistic Thought Regarding "Nur Muhammad"}

There are two different views held by Muslim philosophers regarding the radiance/bestowment of "Nur Muhammad" from the Dzāt of Allah SWT to His Creation. Known

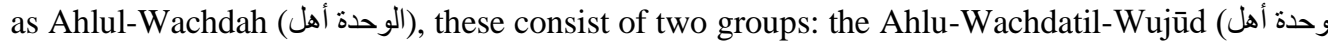
(الوجود), with its leading figures being Syaikh Hamzah Fansuri, Syaikh Syamsuddin As-Samatrani, and its followers [21]; and the second being the Ahlu Wachdatisy-Syuhūd (الثهود وحدة أهل) with their leading figures being Syaikh Nuruddin Ar-Raniri and his followers. A number of subjects related to the spread of "Nur Muhammad" from Dzāt Allah to His Creation, including humanity, are discussed below.

The radiance/bestowment of "Nur Muhammad" from Dzātul-Lāh, Shifātul-Lāh, Asmā'ulLāh, and Af"ālul-Lāh may be explained as follows. Dzāt Allah SWT is located in a place that is not sensory (1ā ta ayyun تنَيُنْ لا) and transcendent (tanzīh تنزيه). Allah SWT is azali (without beginning) and abadi (without end), such that His wholeness, His Dzāt, cannot be comprehended by the human mind or senses. As such, humans who dedicated their efforts to comprehending Him are believed to be undertaking a pointless endeavor, and thus seen as only wasting their lives [12].

Allah SWT first manifested Himself through "Nur Muhammad", which was radiated/bestowed together with His seven characteristics: Chayāt (life), 'Ilmu (knowledge), 
Qudrah (power), Irādah (will), Samā’ (attention), Bashar (sight), and Kalām (speech). These seven characteristics were granted to humanity and manifested in the human soul. The human soul also consists of four elements: Wujud Allah (the manifestation of Allah), Ilmu Allah (the knowledge of Allah), Nur Allah (the light of Allah), and Syuhūd Allah (the oneness of Allah). The first light to shine on and radiate through/be bestowed upon the universe was Nur Muhammad. As such, the human soul and body consists of four elements, listed variously as earth, water, air, and fire [22] and fire, water, air, and earth [13]. Earth is the manifestation of Allah SWT as the Chakim (All-Knowledgeable), water is the manifestation of Allah SWT as Muchȳ̄ (the All-Lifegiving), air is the manifestation of Allah SWT as Qawwī (the All-Mighty), and fire is the manifestation of Allah SWT as 'Azhīm (the All-Glorious). The seven

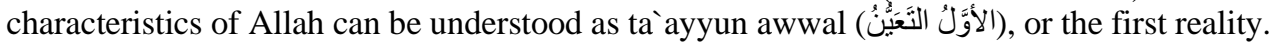

Following the Dzāt Allah SWT and His characteristics, "Nur Muhammad" was radiated/bestowed to Asmā'ullāh (the names of Allah). These asmā'ul-Lāh (الله أسنمَاءُ), ninety-nine in number and known as Asmā'ul-Chusnā (الحسنى الأسماء) are recognized as conveying the diverse traits of Allah. The Asmā'ul-Lāh are seen as part of His Dzāt, Wujūd, and essence. As such, this

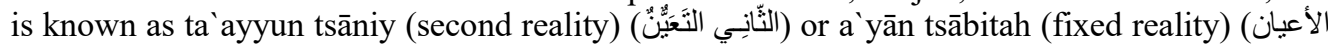
(الثابتة).

Allah SWT released Asmā'ul-Lāh (الله أسنَْاءُ) from ta`ayyun tsāniy (the second reality) (الثَّانِي النَعَيُّنُ) or a'yān tsābitah (the fixed reality) (الثابتة الأعيان) to a'yān khārijiyyah (the reality outside Allah's Dzāt, Wujūd, and Essence) (الخارجيّة الأعيان). This takes the form of af alul-Lāh (Allah's deeds), enabling af alul-Lāh (الله أفعال) to be understood and perceived by the human being human senses and mind.

The problem and source of conflict is the process through which "Nur Muhammad" from

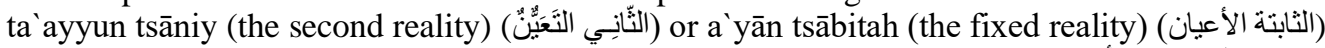
to a yān khārijiyyah (the reality outside Allah's Dzāt, Wujūd, and Essence) (الخارجيّة الأعيان).

According to the Ahlu Wachdatil-Wujūd, "Nur Muhammad" was not spread at the time of Creation, but together with tajalliy (تَبَِّّي); as such, Dzātul-Lāh, Shifātul-Lāh, Asmā'ul-Lāh and Af ālul-Lāh are one and the same, an inseparable unit known as Wachdatul-Wujūd. Meanwhile, according to the Ahlu Wachdatil-Syuhūd, the process through which "Nur Muhammad" was

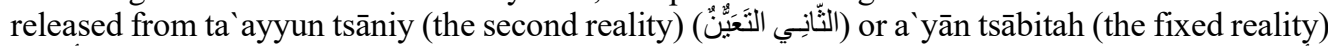
الأعيان (الثابتة الأعيان) to a yān khārijiyyah (the reality outside Allah's Dzāt, Wujūd, and essence) occurred together with Creation. As such, the connection between the transcendent Wujūd (Dzātul-Lāh, Shifātul-Lāh, Asmā'ul-Lāh) and immanent Maujūd (Af́ālul-Lāh) is the connection of Khāliq (Creator) and Makhlūq (Creation). In other words, they are not a single unit, but rather two units in a causal relationship, with Allah SWT and His Creation having a perceptible connection, albeit a close one with tabir (boundaries). The Ahlu Wachdatil-Syuhūd

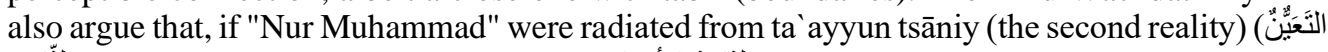
(الثّانِي (الثابتة الأعيان) or a yān tsābitah (the fixed reality) to à̄n khārijiyyah (the reality outside Ällah's Dzāt, Wujūd, and Essence) (الخارجيّة الاعيان), it would become less powerful as distance increased; this is not a characteristic, they hold, of "Nur Muhammad". As such, the Ahlu Wachdatil-Syuhūd view "Nur Muhammad" not as light being radiated or tajalliy (تَجَبَِّيَ), but light bestowed, with full power or faidhun, tafwīdh (تَفِْْضْ فَيْضِن، no matter the distance.

\section{Guidance for Worship and Pilgrimage}

Solemn (khusu') worship is one means of connecting one's soul with Allah SWT. As such, by praying solemnly five times daily, one will establish a clear position as the servant of Allah 
SWT through "Nur Muhammad". One's use of solemn prayers, punctually five-times daily, will bring light to one's heart, as mentioned in the following hadith:

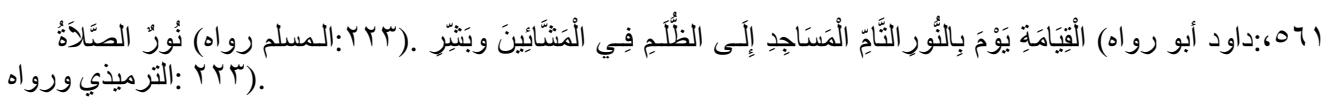

This means: Prayer is light (HR. Muslim no. 223). In a hadith from Burairah, the Prophet SAW states: "Share the good news with those walking to the mosque in the dark, for they will receive perfect light on the Last Day." (HR. Abu Daud no. 561 and Tirmidzi no. 223).

Furthermore, Allah SWT provided a great blessing to all those who complete their Friday prayers, as one benefit of Friday prayers is the mitigation of one's sins and mistakes, as well as the strengthening of one's piety, bi idznillah, as mentioned in the following hadith.

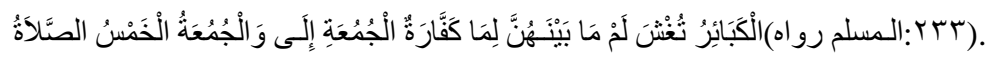

This means: "Five-time prayers, the first Friday prayer, and subsequent Friday prayers, these can erase your sins, so long as these sins were not serious" (HR. Muslim no. 233).

Meanwhile, as widely known, the hajj pilgrimage is considered a glorious and noble form of worship. This worship is one of the pillars of Islam, compulsory for all Muslims with the necessary ability. The importance of the hajj is frequently mentioned in the Quran and Sunnah. It is important, for example, because people who go on the hajj pilgrimage will receive a heavenly blessing. The hajj pilgrimage is the greatest form of worship, as mentioned in the following hadith.

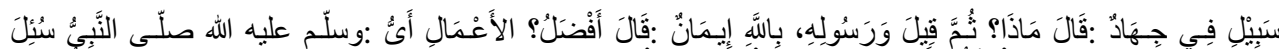

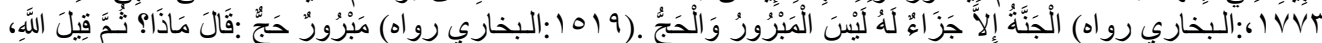

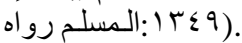

This means: "The Prophet SAW was asked, "What charitable practice is the greatest?" The Prophet SAW answered, "Being faithful to Allah and His Prophet." Another asked, "What else?" The Prophet SAW answered, "Fighting faithfully on Allah's path." Another asked, "What else then?" "The great hajj pilgrimage", answered the Prophet SAW" (HR. Bukhari no. 1519). Furthermore, according to Abu Hurairah, the Prophet SAW also said: "and the hajj has no more appropriate reward than in heaven" (HR. Bukhari No. 1773 dan Muslim no. 1349).

Allah created "Nur Muhammad", "Hakikat Muhammad", or "Ruh Muhammad", before He created everything. As such, "Nur Muhammad" is considered the foundation, source, or basis for all Creation. It was transcendent, without an object of creation, and without the act of creating Allah could not be termed Khalik. As such, Allah created all beings by radiating/bestowing "Nur Muhammad" so that it could be known and understood. This is reflected in Q.S. An-Nur [24]:35, which states.

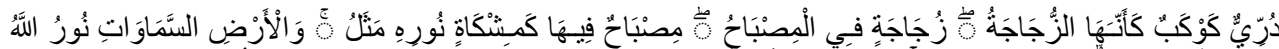

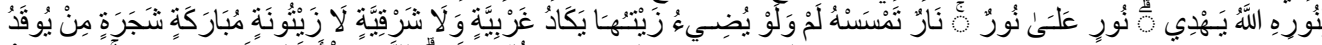

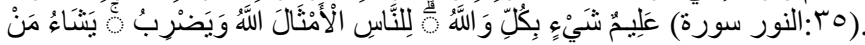

This means: Allah is the Light of the heavens and the earth. The example of His light is like a niche within which is a lamp, the lamp is within glass, the glass as if it were a pearly [white] star lit from [the oil of] a blessed olive tree, neither of the east nor of the west, whose oil would almost glow even if untouched by fire. Light upon light. Allah guides to His light whom He wills. And Allah presents examples for the people, and Allah is Knowing of all things. (Q.S. An-Nur [24]:35).

Regarding "Nur Muhammad", the Prophet SAW also said, in the following hadith: 


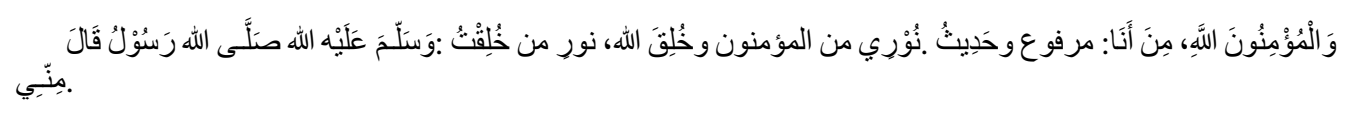

Truly, Allah makes Himself apparent in His servants, and they do not see Him. Because, as humans, they consist of four elements: earth, air, fire, and water. The Prophet Muhammad SAW is seen from his human aspects, for he ate, drank, and married. This factor is very important; the Prophet Muhammad SAW is a manifestation, a perfect radiance from Allah, a perfect being (insan kamil), but the Prophet Muhammad SAW is not Allah. In other words, unlike in pantheism, there is no union of humanity and God. Humans are positioned the highest solely because they provide the most perfect service; they are abdun (servants), who surrender themselves to Allah. Abdun must live in recognition of their position as servants of Allah. Abdun are characterized by surrender. As such, their service is provided not based on obligation or compulsion, but rather the joy of service to Allah.

Shortly, the difference between the Kaaba and Baitullah, are described below. Masjid AlHaram is said to surround the Kaaba in Mecca, and thus this is the direction Muslims face when praying. Literally defined, masjid (مسجد) means "a place of prostration", and the word al-Charam (الحرام) means "holy". Meanwhile, the word Baitullah means "the house of Allah, the palace of Allah". In other words, Baitullah is located at Masjid al-Haram, and the house of Allah or the palace of Allah is in a holy place. As such, Baitullah (the house of Allah or palace of Allah) is found within the hearts of the pious, the devout whose worship is solemn, the devoted who do good deeds. As such, human beings should be a sacred place of rest. They are Baitullah, able to receive the radiance or bestowment of "Nur Muhammad" and spread it to others, thereby bringing them light.

Baitullah is symbolized in Mecca through the Kaaba. However, understood as the house of Allah or the palace of Allah, Baitullah is located somewhere inconceivable to humans, transcendental and unable to be sensed. How, then, can the pious enter Baitullah and meet Allah? Where is Allah's justice, that the pious must travel such distance to visit Him in Mecca? Especially since some say that, during the hajj season, Allah is receiving His guests in Mecca. What is the position of Masjid al-Haram according to the Quran? Wherever humans go, they must turn their faces to Masjid al-Haram, as stated in Q.S. Al-Baqarah [2]:149, and wherever they are they must turn their faces to Masjid al-Haram, as stated in Q.S. Al-Baqarah [2]:150. Is Masjid al-Haram the Great Mosque in Mecca? Must Muslims always face the direction of Mecca in prayer? What of drivers, pilots, and railroad engineers? Wherever one faces, Allah is there, as stated in Q.S. Al-Baqarah [2]:115. As such, Allah is everywhere, not bound by distance or direction. Every one of the faithful is a direction toward which he or she faces, so all must race to that which is good, as stated in Q.S. Al-Baqarah [2]:148.

Where, then, is Masjid al-Haram? Allah is nearby, not far, as stated in Q.S. Al-Baqarah [2]:186; He is with humans wherever they are, as stated in Q.S. Al-Hadid [57]:4; He is closer than the tendons in one's neck, as stated in Q.S. Qaf [50]:16. So what, then, is the essence of Baitullah? The essence of Baitullah lies in the haram or pure soul. Not all humans have Baitullah; it is found within the hearts of the pious who pray solemnly, within the hearts of those who do good deeds, as stated in Q.S. An-Nahl [16]:128. If we seek to become Baitullah, we must become pure or holy places of refuge. This is done by being faithful, by associating others with Allah, as stated by Q.S. Al-Inshiqaq [84]:6. This is the essence of Baitullah.

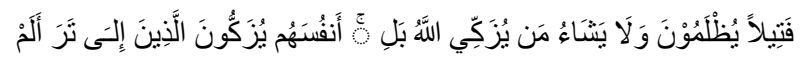

Or, translated: Have you not seen those who claim themselves to be pure? Rather, Allah purifies whom He wills, and injustice is not done to them, [even] as much as a thread [inside a date seed]. (Q.S. An-Nisa' [4]:49). 
Pure and clean souls that can become Baitullah are symbolized as beautiful birds. Allah created a beautiful bird, consisting of a head (Ali ibn Abi Thalib), two eyes (Hasan and Husain), shoulders (Fatimah Az-Zahra), wings (Abu Bakar and Umar ibn al-Khath-thab), chest (Hamzah ibn Abdul Muthalib), and rear (Abbas and the Prophet's wives Siti `Aisyah and Siti Khadijah) (Ar-Raniry in Hikayat Nur Muhammad, n.d.:7). The souls and hearts of the Prophet Muhammad SAW's family were pure and clean, and could thus become Baitullah. They could share "Nur Muhammad", and thereby provide guidance to all humans on earth. Humans are the most important factor in one's education process [23] [24].

\section{Conclusion}

The word nūr has two meanings: the material (concrete, worldly) and spiritual (abstract, heavenly). Understood materially, nūr is a bright and clear light, one perceptible to the senses and visible to the eyes, one that brings light to objects and makes them visible. Meanwhile, the word nūr can be understood spiritually as direction or guidance, the Quran, the light felt by those who are solemn in their prayers. This nūr is located within Baitul-Lāh, and becomes apparent only in the hereafter. As such, the "Nur Muhammad" concept refers to the process through which Sufis seek perfection (i.e. to become insan kamil), the highest level of Ma rifatul-Lāh or humanity. They seek "Nur Muhammad" (the essence of Muhammad or the spirit of Muhammad), such that they can interact directly with Baitul-Lāh.

Meanwhile, regarding the dispute between the Ahlu Wachdatil-Wujūd or the Ahlu WachdatilSyuhūd regarding "Nur Muhammad" and the creation of the universe, including humanity, the writer concludes:

The Ahlu Wachdatil-Wujūd argue that the Prophet Muhammad SAW was created from "Nur Allah", as "Nur Muhammad". According to this group, the release of "Nur Muhammad" from ta ayyun tsāniy (the second reality) or a'yān tsābitah (the fixed reality) to a'yān khārijiyyah (the reality outside Allah's Dzāt, Wujūd, and essence) occurred not together with Creation, but through radiance or tajalliy. In other words, Allah SWT radiated His light to the Prophet Muhammad SAW, after which "Nur Muhammad" was radiated further to the devout and pious. As such, Allah and the universe are understood as being inseparable, as being a single unit. This is supported by the concept of Ma rifatul-Lāh (the highest level of humanity); it is recommended that whoever reaches the level of Ma rifatul-Lāh not share knowledge with those lacking it, in order to avoid creating unrest and deviance in society.

Meanwhile, the Ahlu Wachdatil-Syuhūd hold that "Nur Muhammad" was not light radiated or tajalliy, but bestowed from its source, Nur Allah. As such, the light remains strong no matter the distance between its source and the beings receiving it. Furthermore, were Creation to involve the radiance of "Nur Allah" through "Nur Muhammad", the greater the distance between the source and the recipient the weaker it would become. This view is supported by the understanding that "Nur Muhammad" is bestowed upon Creation through a causal relationship, rather than being a single unit.

Humans are created by Allah, live to serve and worship Him, and ultimately return to Him. As such, humans are created from the earth and born in a state of fitrah (purity, cleanliness). Over the course of their lives, from birth through old age, humans use the fertile land provided by Allah. They may do good deeds or bad deeds, but these serve only as provision for the afterlife. In other words, humans are created by Allah in a state of fitrah (purity, cleanliness), but lose this purity after being contaminated by life on earth; they must cleanse themselves to ensure 
they return to Allah in a state of fitrah (purity, cleanliness). As such, to ensure humans remain in a state of fitrah (purity, cleanliness) and can return to Allah SWT, they require charitable actions and devout worship. Only then can they cleanse their souls (tazkiyyatun-nafsi) and become pious people controlled, guided, directed, and nurtured by the light of "Nur Muhammad". They must do good deeds and avoid associating anyone in the worship of their Lord, as stated in Q.S. Al-Kahfi [14]:110). Furthermore, to ensure they remain illuminated by "Nur Muhammad", they must worship solemnly and go on the hajj. Only then will they become insan kamil capable of reaching Baitul-Lāh. As such, humans are created by Allah SWT to worship Him, and will ultimately return to Him.

\section{References}

[1] F. Al-Burhanpuri, At-Tuchfatul-Mursalah ila Rasulin-Nabiy Shallallahu `alaihi wa sallam. Banda Aceh: Collection of the Aceh Special Administrative Region Provincial Museum.

[2] Biyanto, "The typology of Muhammadiyah Sufism: Tracing its figures' thoughts and exemplary lives,” Indones. J. Islam Muslim Soc., vol. 7, no. 2, pp. 221-249, 2017.

[3] A. Muhammad and Dian, "the Development of Teacher Characters Basis of Tasawuf," J. Pendidik. Islam, vol. 1, no. 3, p. 327, 2015.

[4] E. Al-Haramain, "Shifting orientation in Sufism: Its development and doctrine adjustment in history," Indones. J. Islam Muslim Soc., vol. 1, no. 2, pp. 273-296, 2011.

[5] Sangidu, "Penyajian dan Interpretasi Teks Sastra Indonesia Klasik Khususnya Naskah-Naskah Jawi dan Naskah Berbahasa Arab,” Humaniora, vol. 11, no. 1, pp. 110-120, 1999.

[6] S. Baroroh-Baried, S. C. Soeratno, Sawoe, S. Sutrisno, and Moh Syakir, "Pengantar Teori Filologi," Yogyakarta, 1994.

[7] Junaidi, "Naskah Kuno Melayu Riau sebagai Sumber Penciptaan Karya Sastra Masa Kini,” J. Ilmu Budaya, vol. 7, no. 1, pp. 1-6, 2010.

[8] S. D. Damono, Sosiologi Sastra Sebuah Pengantar Ringan. Jakarta: Pusat Pembinaan dan Pengembangan Bahasa, 1984.

[9] T. Iskandar, Bustanus-Salatin. Kuala Lumpur: Council of Language and Literature, Malaysian Ministry of Education, 1966.

[10] S. Zalila and J. H. Ahmad, Kesusastraan Melayu Tradisional. Kuala Lumpur: Council of Language and Literature, Malaysian Ministry of Education, 1993.

[11] U. Hamidy, "Naskah Kuno Daerah Riau sebagai Sasaran Kajian Sastra Islam," in Analisis Kebudayaan, 1984, vol. IV No.2, pp. 57-70.

[12] Sangidu, Polemik Pemikiran Sufistik antara Hamzah Fansuri dan Syamsuddin AsSamatrani dengan Nuruddin Ar-Raniri. Yogyakarta: Gama Media, 2008.

[13] N. Ar-Raniri, Hikayat Nur Muhammad. Banda Aceh: Collection of the Aceh Special Administrative Region Provincial Museum,.

[14] H. R. Jauss, Towards an Aesthetic of Reception. Minneapolis: University of Minnesota 
Press, 1982.

[15] D. W. Fokkema and Elrud Kunne-Ibsch, Theories of Literature in the Twentieth Century. London: C. Hurst \& Company, 1977.

[16] W. Iser, The Act of Reading: A Theory of Aesthetic Response. London: The John Hopkins Press, 1987.

[17] R. T. Segers, The Evaluation of Text. Lisse: Peter de Ridder Press, 1978.

[18] R. D. Pradopo, Beberapa Teori Sastra, Metode, Kritik, dan Penerapannya. Yogyakarta: Pustaka Pelajar, 1995.

[19] S. C. Soeratno, Chamamah-Soeratno, Siti. Hikayat Iskandar Zulkarnain. Jakarta: Balai Pustaka, 1991.

[20] A. Teeuw, Sastra dan Ilmu Sastra: Pengantar Teori Sastra. Jakarta: Pustaka Jaya, 1984.

[21] H. Fansuri, Syarābul-'Äsyiqīn. Banda Aceh: Collection of the Aceh Special Administrative Region Provincial Museum.

[22] N. Ar-Raniri, Mā'ul-Chayāt li Ahlil-Mamāt. Banda Aceh: Collection of the Aceh Special Administrative Region Provincial Museum.

[23] A. B. S. Ismail and Nor Aishah Buang, “"Development of Entrepreneurship Intentions Among School Students in Malaysia," IJOLAE Indones. J. Learn. Adv. Educ., vol. 1, no. 1 , pp. $48-53,2019$.

[24] H. J. Prayitno, A. Ngalim, A. Sutopo, D. W. Pangestu, N. Jamaluddin, and A. H. Ali, "Directive Politeness Act Strategy in The Discourse of Education Column in National Newspaper as The Formation Of Students' Character in Indonesia," Humanit. Soc. Sci. Rev., vol. 7, no. 1, pp. 349-36, 2019. 